\title{
Application of new measurement technology for deformation study of structures in mining areas
}

\author{
Piotr Gruchlik ${ }^{1, *}$, and Andrzej Kowalski ${ }^{1}$ \\ ${ }^{1}$ Central Mining Institute, Department of Surface and Structures Protection, 1 Gwarków Sq., 40-166 Katowice, Poland
}

\begin{abstract}
Despite of classic geodetic measurements, which are used in mine surveying at the beginning, more new technology are applied to measure deformation of structures and surface in mining areas. In the article new technologies are described for utilitarian aims based on strain sensors, laser, scanners and drones. The application of new technologies are especially useful when direct access to measured object is impossible using classic methods and in situation where continuous or quasi-continuous measurement is necessary. In Central Mining Institute the research has been conducted to understand the phenomenon of surface deformation induced by underground mining comparing predicted and measured values before and after extraction. In the last 20 years the mining technology has changed and dynamics of structure and surface deformation induced by mining. The second reason of technology development is necessity to instantly inform users of land and structures about changes using for instance the Internet.
\end{abstract}

\section{Introduction}

New survey technology (sensors, inclinometers, extensometers, laser, terrestrial and aerial laser scanning - LIDAR - Light Detection and Ranging) extents monitoring of surface deformation. However, these technologies can't measure everything because they have some limitations. The ideal method doesn't exist.

Geodetic surveys still are basic and reference methods, which give information about coordinates of points on the bare-earth and structures. They may also give information about changes in time. Development of mining technology induces increasing deformation of surface land and structures and includes sizeable area. Second aspect that enforces application of new survey technology is reaction of citizens on negative results of underground mining. The users of structures and land expect instantly information about deformation and warnings of usage risk.

In Central Mining Institute the research has been conducted to understand the phenomenon of surface deformation induced by underground mining comparing predicted and measured values before and after extraction. It's significant because without survey the knowledge is blind [1].

In recent years in Central Mining Institute new survey technology has been used to monitor of sacral and industrial buildings as supplementation of geodetic measurements.

Interpretation of both ways to store data enables to better understand the phenomenon of deformation. Correctly designed monitoring of deformation process should include not only way of getting data but also allow for correct interpretation. The results should give the answers for questions such as: will goals be achieved, how to change the mining and structures prevention and is changing survey method is necessary?

\section{New survey technology}

\subsection{Extensometers and inclinometers}

Extensometers and inclinometers are applied to measure deformation of structures in mining areas. They are usually connected with others devices, which play function as receiver or transmitter or both. Setting of suitable system with algorithms may enable to provide automatic measurements for long time. Wireless monitoring system of structure construction includes:

- string extensometers to measure linear strains or width of cracks,

- string inclinometers to measure three dimensional inclination of building.

First instruments were constructed in The Strata Mechanics Research Institute of the Polish Academy of Sciences [2]. The system has been applied for remote monitoring of building construction of Lutheran Church in Bytom-Miechowice (compare section 2.2) induced by longwall 18a in lower layer of 510 seam extracted during 2011-2012, Fig. 1 [3]. In this church cracks on walls and roofs have emerged. The construction of the building has been induced by uneven subsidence.

Surveys proved that system was working well to monitor deformation of construction of the church building during deformation of ground induced by mining in terms of time. Three dimensional surveys of 
the church tower enabled to indicate main directions of inclination.

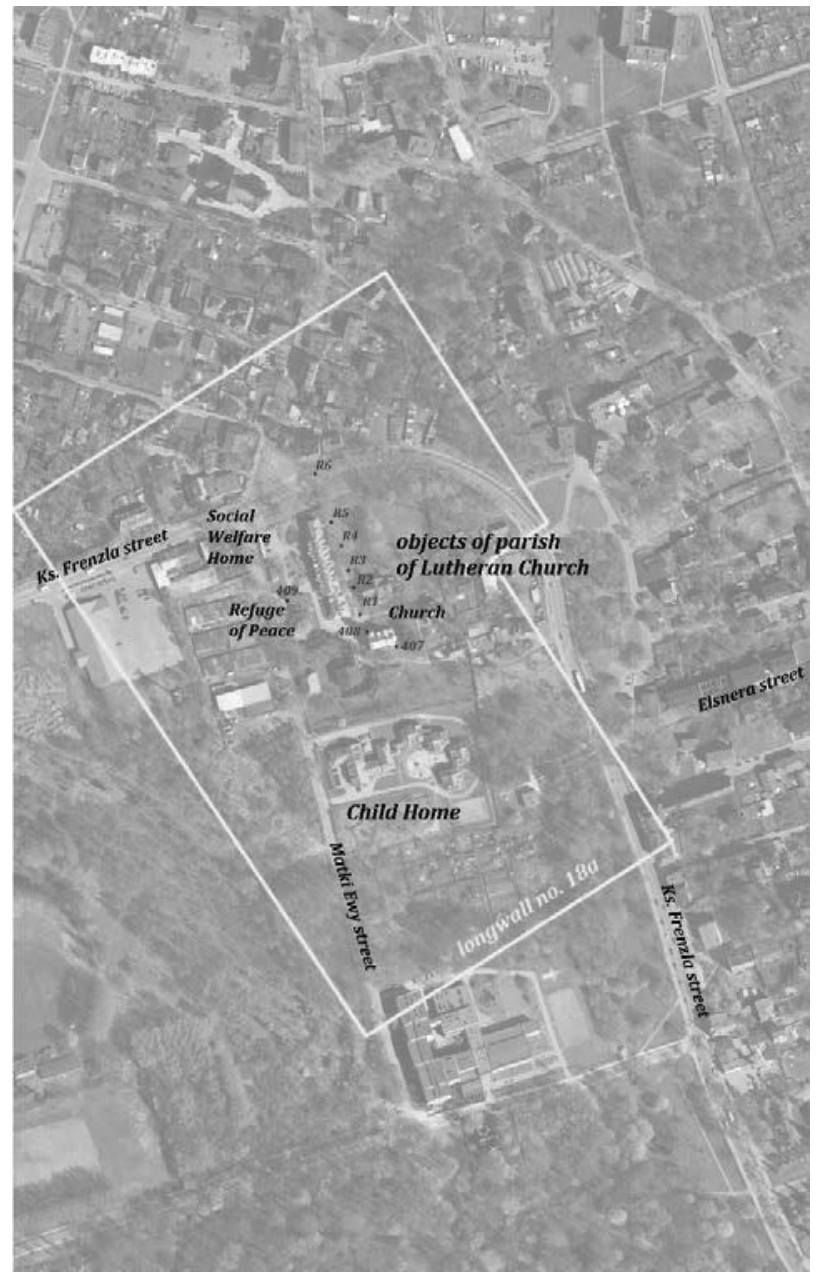

Fig. 1. The fragment of the measured power line and the set measuring instrument [3].

Sensitivity of the system enables to monitor small changes of strains. Disadvantage of the system is the scattered observation status. Considering small number of sensors there is risk to miss some significant information about a reaction of building construction. Despite of numerous advantages, the remote system cannot be the only one tool to monitor a condition of the object.

Another but similar system has been applied in two viaducts (road and tram viaduct) in Ruda Śląska (Fig. 4). The monitor system includes twelve sensors as follows:

- eight crackmeters (Geokon 4420) to measure displacement increments of deck in term of abutments along y axis,

- four vibrating wire tiltmeters (Geokon 6350) to measure inclination of abutments along two perpendicular planes and 16-channel recorder to store data.

First results of the measurement have been read 30 days time. Later monitoring system was extent by next four sensors. In the meantime, the system of storing and processing data has been replaced with new one to measure tilts and displacements in real time.
Received displacement increments of road viaduct abutments in real time were similar to predicted value. Whereas, displacement increments of tram viaduct were completely different than the predicted values. It may be interpreted as viaduct work.

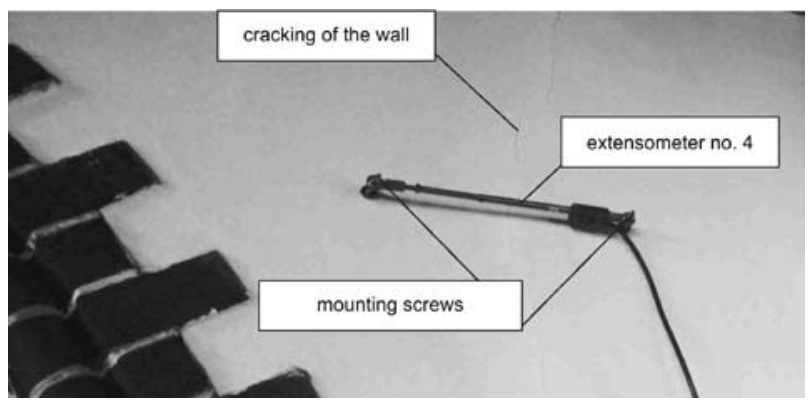

Fig. 2. Installation of extensometer number 4 over the crack of the wall nearby main entrance of the church [4].

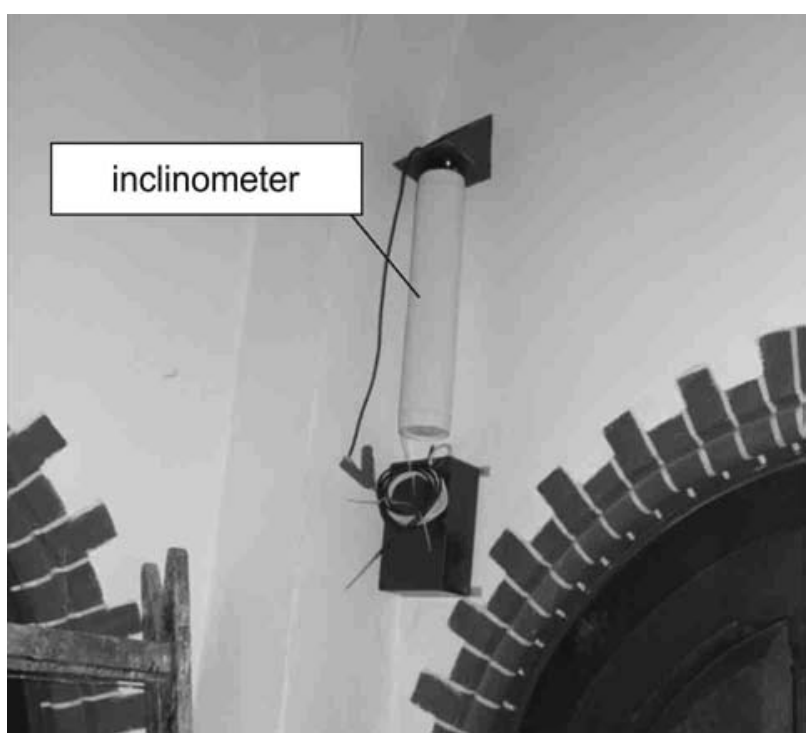

Fig. 3. Installation of inclinometer in quoin of the church tower [4].

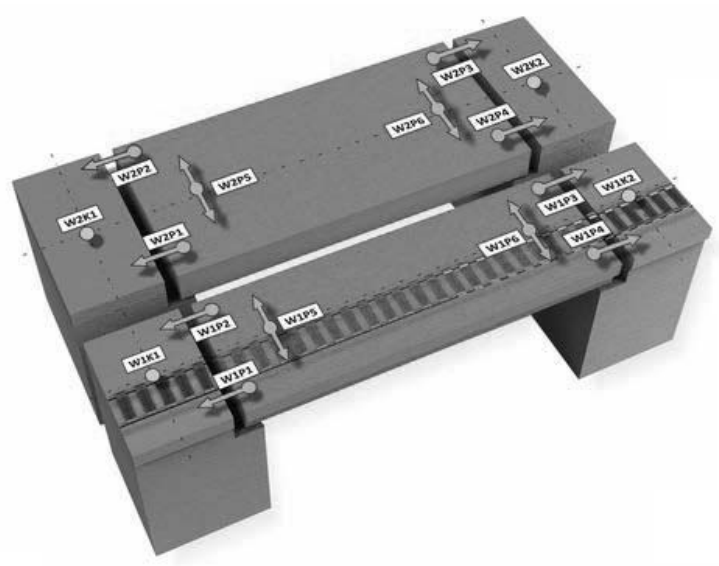

Fig. 4. Arrangement of sensors on tram and road viaduct designed to measure displacement increments (WP) and arrangement of inclinometers (WK). 


\subsection{Extensometers and inclinometers}

The discussed laser sensors for inclination and acceleration measurements are designed by Central Mining Institute. Sensors provide accurate and continuous work to measure inclination of structure. The output data can be shown on the graphical chart or recorded in memory of decoder including values of inclination (millimeter per meter unit), directions of inclination (e.g. related to cardinal directions) and time of registered data. Principle of survey is based on recording track of laser beam from vertical plane after passing through liquid wedge.

Specification of sensor is as follow:

- defined measurement range $+5 \mathrm{~mm} / \mathrm{m} \mathrm{mm} / \mathrm{m}$, (range of sensor 2-50 $\mathrm{mm} / \mathrm{m}$ ),

- resolution: $+0.02 \mathrm{~mm} / \mathrm{m}$,

- frequency of vibration $<10 \mathrm{~Hz}$,

- power supply voltage of device: $220 \mathrm{~V} \mathrm{~A} / \mathrm{D}, 50 / 60$ $\mathrm{Hz}$,

- power consumption $<2 \mathrm{~W}$.

Recording system consists of multichannel A/D converter with resolution 12-bit, PC computer and hard disc drive. Controlling of recorder, viewing and transmission data are able trough website using GPRS technology.

Inclination sensor and digital recorder were installed in steal covers on south-east side of "Terma-Dom" chimney base about $2 \mathrm{~m}$ above the floor in Zabrze (Fig. 5). The chimney was described in details in section 2.3. The monitoring system has been started on the 22.03.2016. The inclination directions of sensor were calibrated according to cardinal directions. Before field use it had been tested in the laboratory on swing table with micrometer screw.

In the first period of measurements inclination increments of chimney were affected by atmospheric factors (temperature, wind, sun exposure). Temporary chimney inclination of about $+0.05 \mathrm{~mm} / \mathrm{m}$ has occurred because of wind pressure (average wind speed equalled $7 \mathrm{~m} / \mathrm{s}$ ).

Next, daily increments of chimney inclination are shown in Fig. 6. Fig. 7 shows values of resultant vector in plane $\mathrm{X}-\mathrm{Y}(\mathrm{S}-\mathrm{N}-\mathrm{W}-\mathrm{E})$. Based on the mentioned charts, temperature (and sun exposure) above $10^{\circ} \mathrm{C}$ triggers chimney inclination in south-west direction $(-0.3$ $\mathrm{mm} / \mathrm{m}$ south for temperature $25^{\circ} \mathrm{C}$ ). Temperature below $10^{\circ} \mathrm{C}$ induces inclination in opposite direction $(0.4$ $\mathrm{mm} / \mathrm{m}$ north for temperature $1^{\circ} \mathrm{C}$ ). Between 28 of June to 8 of July direction of chimney inclination was southeast, whereas from 14 to 31 of July rapidly had been change to south-west. The highest values of vector components $(1.3 \mathrm{~mm} / \mathrm{m}$ west and $1.89 \mathrm{~mm} / \mathrm{m}$ south $)$ has been recorded between 4 and 5 of August.
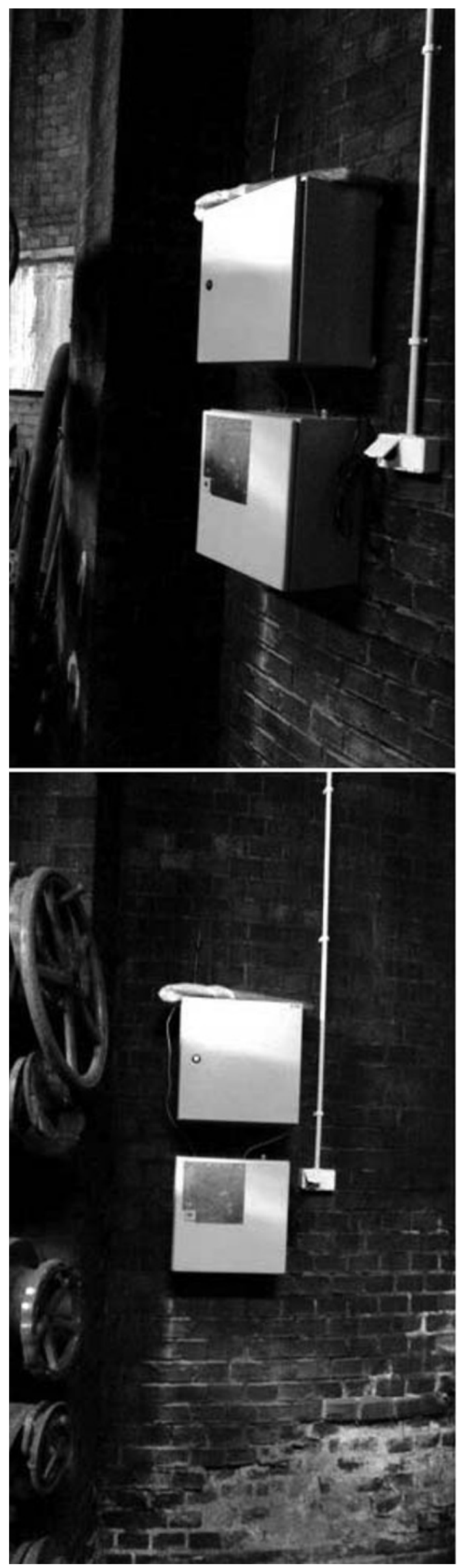

Fig. 5. The place of sensor installation. 


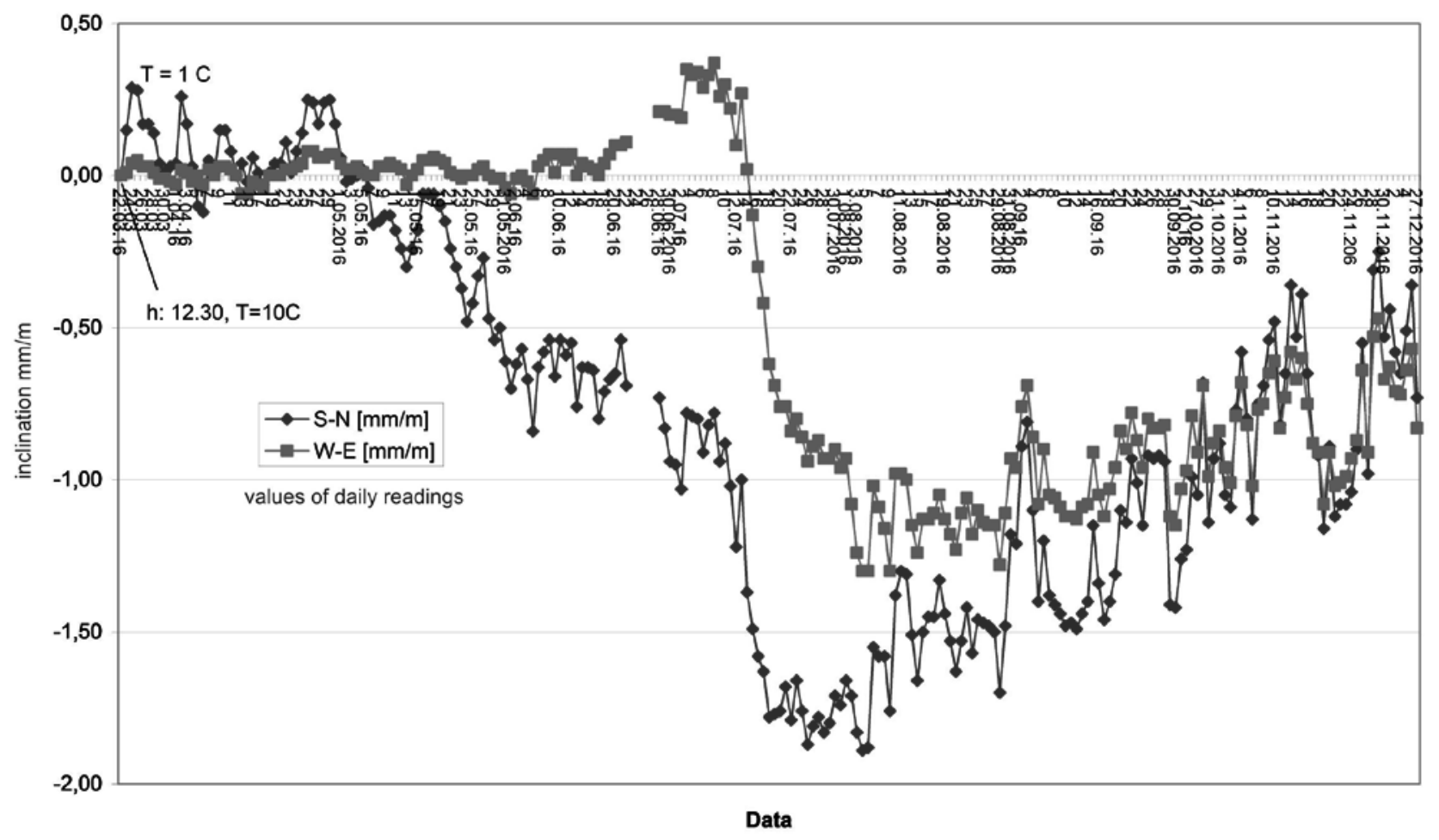

Fig. 6. Inclination distribution of chimney base along W-E and N-S axes.

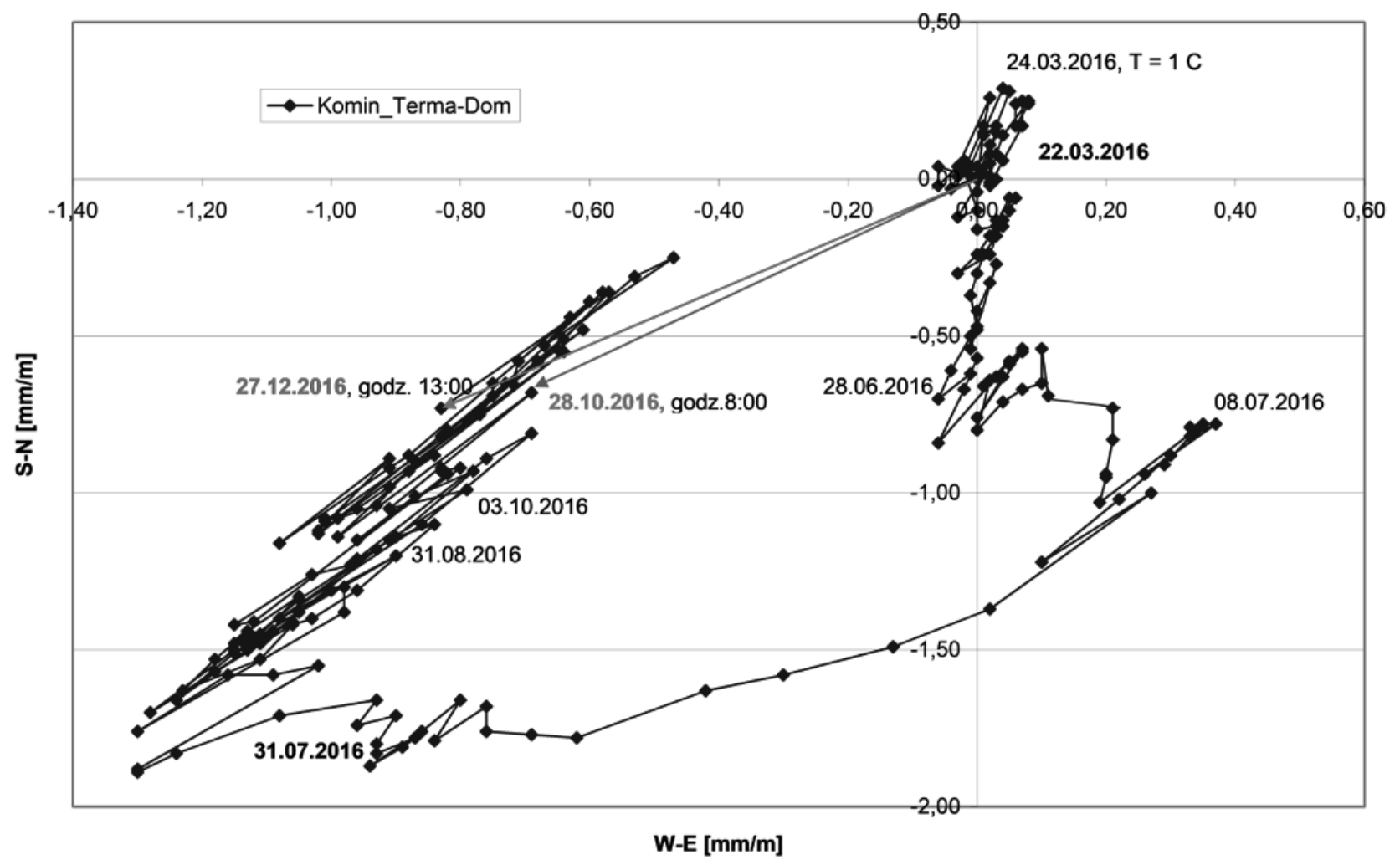

Fig. 7. Inclination vectors of chimney base since the day of sensor installation.

The calculated length of resultant vector is $2.3 \mathrm{~mm} / \mathrm{m}$ in south-west direction according to the first day of storing data. In September 2016 there were periodic sinusoidal changes of direction of chimney inclination $(+0.3 \mathrm{~mm} / \mathrm{m})$. The resultant vector has been decreased by $0.2 \mathrm{~mm} / \mathrm{m}$ in north-east direction. This tendency has been remained until mid-November and the value of resultant vector dropped to $0.72 \mathrm{~mm} / \mathrm{m}$. In December increments of chimney inclination were around mean value of increment of resultant chimney inclination (1.0 $\mathrm{mm} / \mathrm{m}$ south-west) according to the date of first survey. 


\subsection{D laser scanning}

Department of Surface and Structures Protection in Central Mining Institute has 3D laser scanner Trimble TX5, which enables to store data with speed 976000 points per second at a range of up to $120 \mathrm{~m}[5,6]$. For high objects such as chimneys it is possible to use 3D laser scanner Riegl VZ-4000 too (Fig. 8).

Usage of laser scanning technology enables to asses mining activity on structures and asses their resistance to mining deformation of the ground.

The object of scanning was building of Lutheran Church situated on Matki Ewy Street in Miechowice (section 2.1, Fig. 9). Indoor surveys were carried out using 3D Trimble TX5 scanner. The cracks of the church roof are shown in Fig. 9.

With 3D Trimble TX5 laser scanner it's easy to collect data of actual condition of object. The data can be used to design, redesign, and for technical review of structure. It is more convenient to compare the design and as-built state of the building too. Usage of the scanner is wide for example to get cubature of underground workings, dumps and other object with irregular shape.

The second field of scanning was in the area of coke plant placed in Zabrze-Biskupice where the "Siltech" mine extracts coal seams using experimental method leaving the coal pillars between backfilled headings. Fig. 10 shows extracted panels with headings system, observed subsidence during the 2015-2017 period and coke oven battery, $113 \mathrm{~m}$ high "Terma-Dom" chimney, which was captured using the above-mentioned 3D laser scanner on 09.06.2017.

The results of measurements were points cloud and model of chimney (Fig. 11). cross-sections were made to analyze the body of chimney (Fig. 12). Calculated inclination of top of the chimney based on scanning is equal to $575 \mathrm{~mm}$ with azimuth $33^{\circ}$ in mathematical system and $57^{\circ}$ in geodetic system (north-east direction).
Inclination surveys of top o the chimney are carried out by geodetic firm as result of a contract with the owner of the chimney. The first and subsequent measurements have captured the state of this object before and during mining under investigated area. Resultant inclination of top of the chimney is $63 \mathrm{~cm}$ in geodetic system (from north to clockwise). Mean error of inclination equals $\pm 3,0 \mathrm{~cm}$.

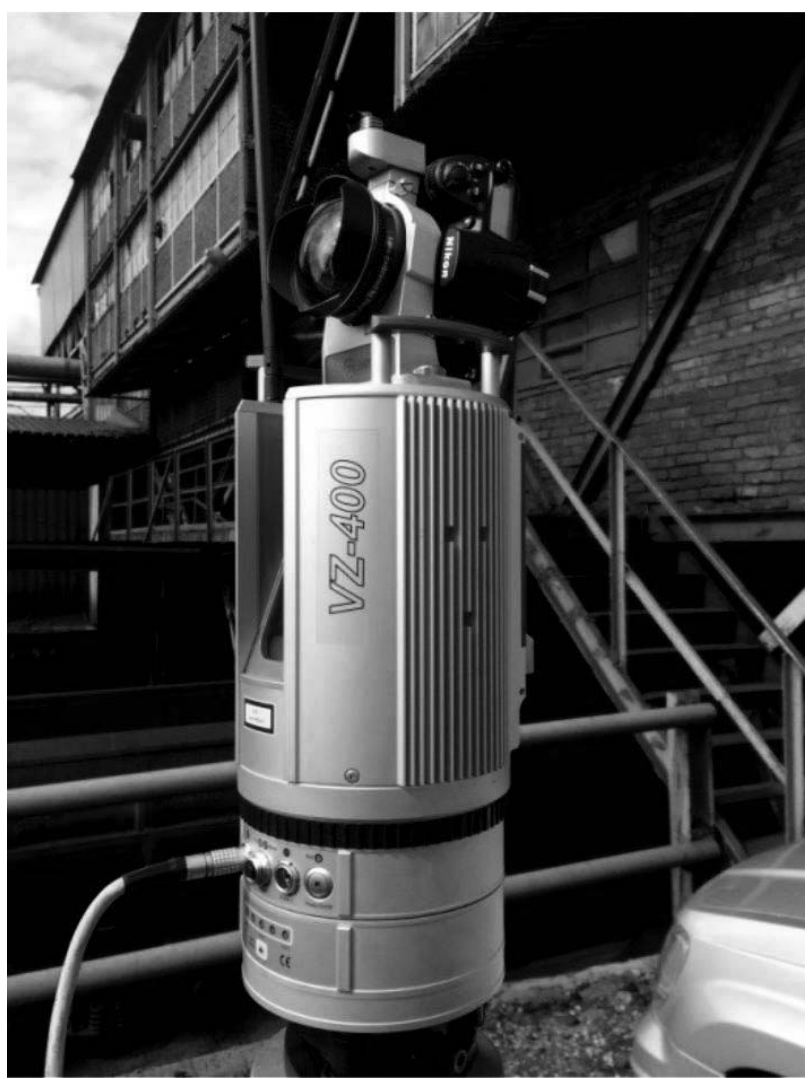

Fig. 8. 3D laser scanner Riegl VZ-400.

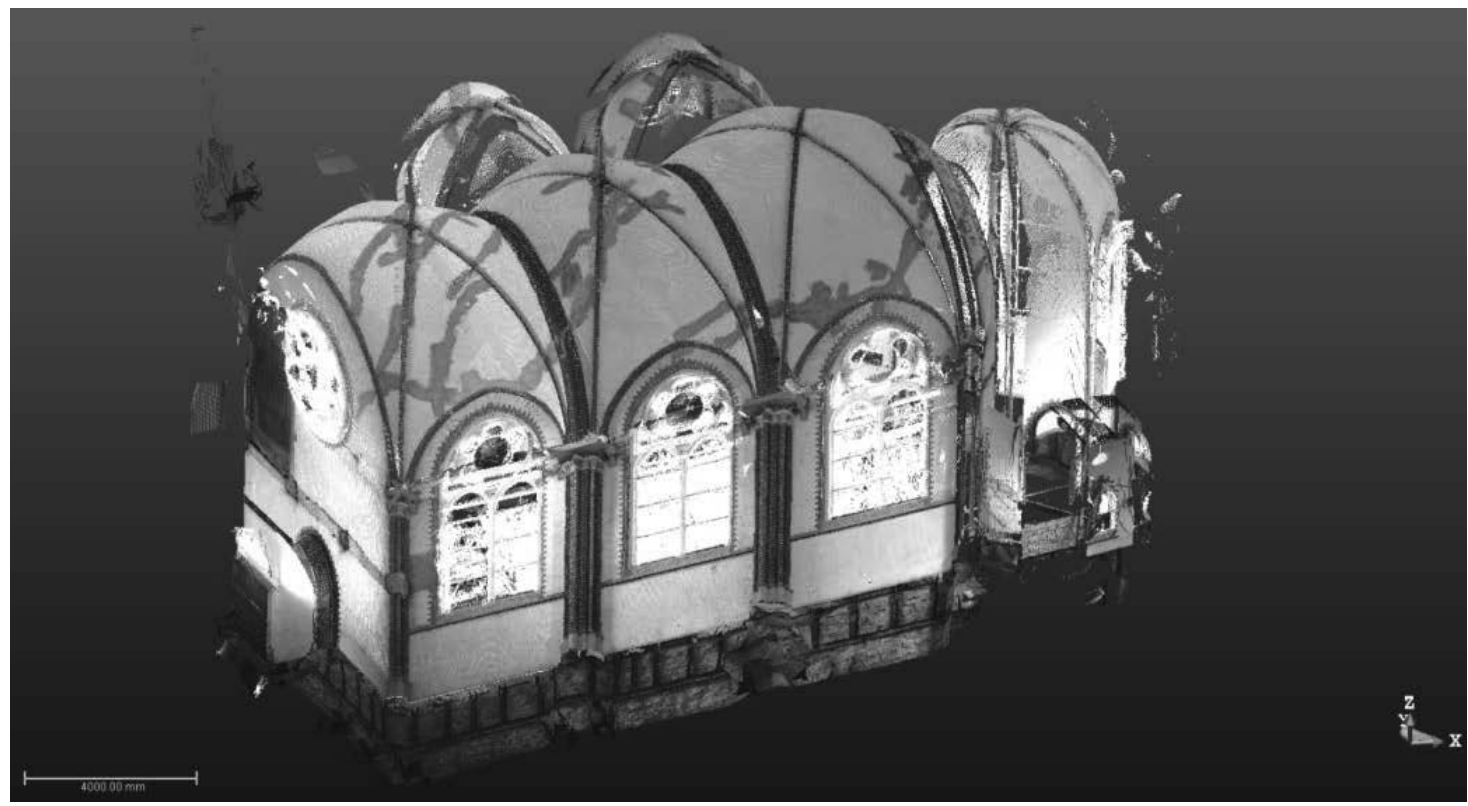

Fig. 9. 3D model of church building based on indoor surveys, north side view [6]. 


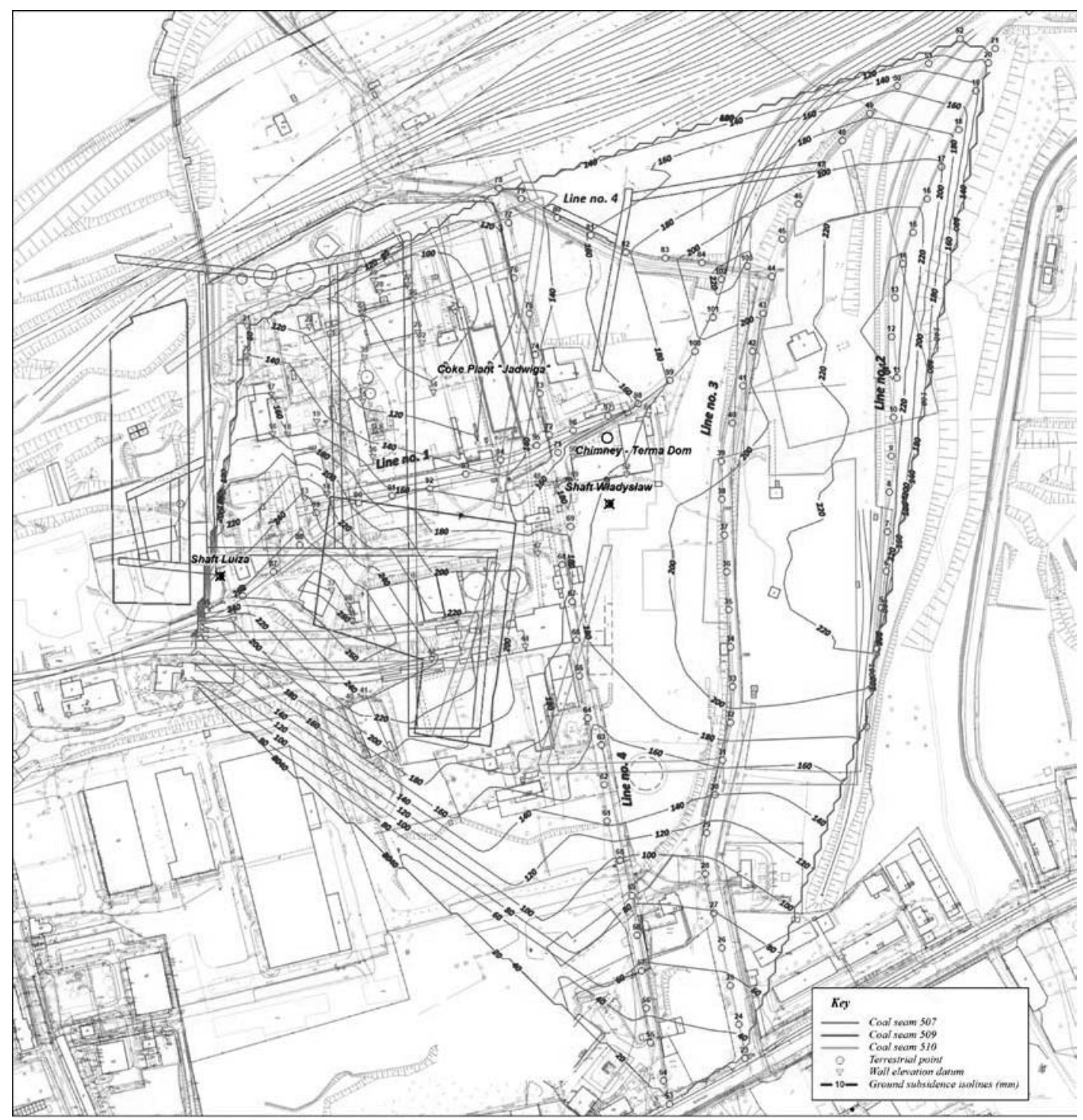

Fig. 10. Extraction of panels and headings in seams 507, 509 and 510 with subsidence contours.

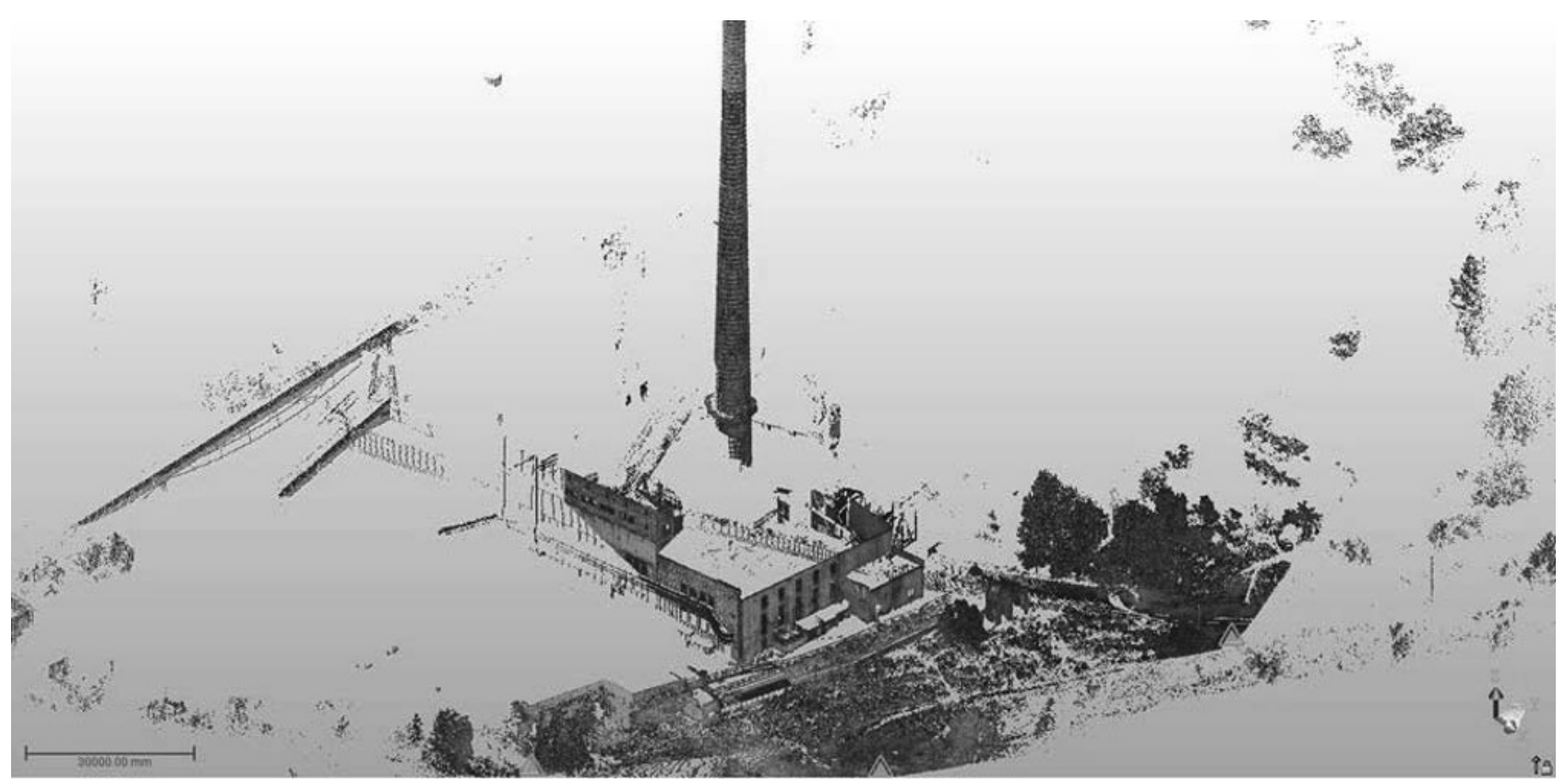

Fig. 11. Registered cloud of points and model of Terma-Dom chimney. 
Tables 1 and 2 include inclinations of top of the chimney using geodetic and scanning methods. Boundary condition of strength based on material strength of top of the chimney is related to horizontal displacement of up to $70 \mathrm{~cm}$.
Historical and up-to-date results of surveys are in Tables 1 and 2. In 2016 the chimney has been affected by mining that resulted in inclination increments up to 6 $\mathrm{cm}$, according to geodetic method and up to $5 \mathrm{~cm}$ according to the scanning one.

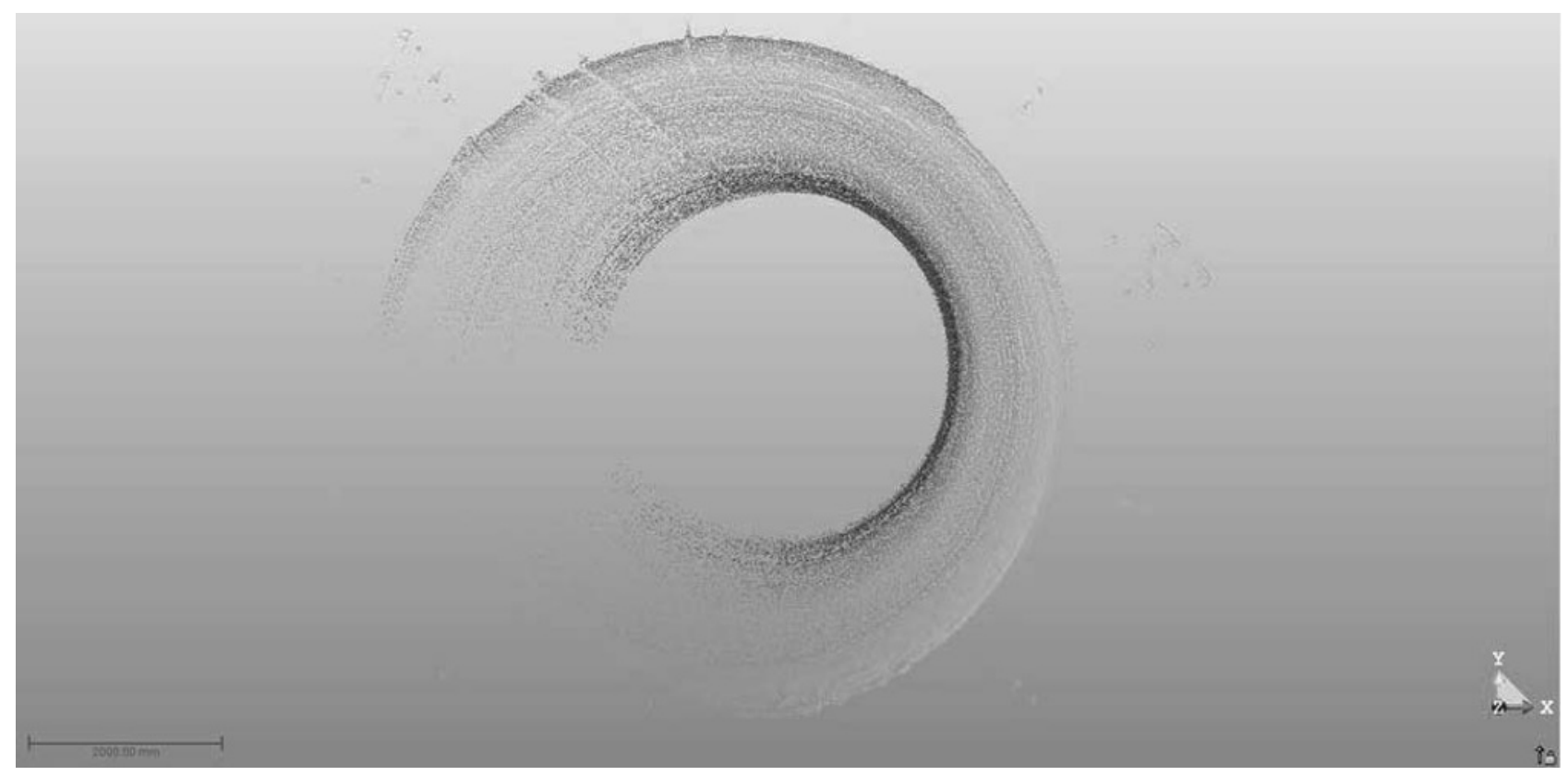

Fig. 12. Horizontal cross sections of $3 \mathrm{D}$ chimney model.

Table 1. Inclinations of top of chimney using geodetic methods.

\begin{tabular}{|c|c|c|c|}
\hline Number of survey & Date of survey & Inclination & Azimuth of inclination \\
\hline 1 & IV.2011 & 57 & $49^{\circ} 51^{\prime}$ \\
\hline 2 & X.2011 & 56 & $52^{\circ} 24^{\prime}$ \\
\hline 3 & XII.2011 & 55 & $55^{\circ} 49^{\prime}$ \\
\hline 4 & IV.2012 & 57 & $55^{\circ} 21^{\prime}$ \\
\hline 5 & X.2012 & 59 & $55^{\circ} 34^{\prime}$ \\
\hline 6 & IV.2013 & 55 & $52^{\circ} 16^{\prime}$ \\
\hline 7 & X.2013 & 60 & $56^{\circ} 56^{\prime}$ \\
\hline 8 & IV.2014 & 55 & $49^{\circ} 32^{\prime}$ \\
\hline 9 & X.2014 & 56 & $51^{\circ} 43^{\prime}$ \\
\hline 10 & III.2015 & 56 & $50^{\circ} 47^{\prime}$ \\
\hline 11 & VII.2015 & 57 & $50^{\circ} 47^{\prime}$ \\
\hline 12 & IX.2015 & 58 & $46^{\circ} 01^{\prime}$ \\
\hline 13 & IV.2016 & 58 & $51^{\circ} 31^{\prime}$ \\
\hline 14 & $29 . I X .2016$ & 64 & $55^{\circ} 27^{\prime}$ \\
\hline 15 & $31 . X .2016$ & 63 & $57^{\circ} 00^{\prime}$ \\
\hline
\end{tabular}


Table 2. Inclinations of top of chimney using laser scanning.

\begin{tabular}{|c|c|c|c|c|c|}
\hline Number of survey & Date of survey & Inclination & $\begin{array}{c}\text { Azimuth of } \\
\text { inclination }\end{array}$ & $\begin{array}{c}\text { Type of } \\
\text { scanner }\end{array}$ & Weather condition in a day of survey \\
\hline 1 & 29.07 .2015 & 56 & $55^{\circ}$ & Trimble TX8 & $27^{\circ} \mathrm{C}, 7,2 \mathrm{~km} / \mathrm{h}$ \\
\hline 2 & 04.11 .2015 & 56 & $51^{\circ}$ & Trimble TX8 & lack of data \\
\hline 3 & 18.03 .2016 & 55 & $54^{\circ}$ & Trimble TX8 & $10^{\circ} \mathrm{C}, \mathrm{W} 34 \mathrm{~km} / \mathrm{h}$ \\
\hline 4 & 21.06 .2016 & 54 & $64^{\circ}$ & Riegl VZ-4000 & $21^{\circ} \mathrm{C}, \mathrm{SW} 14 \mathrm{~km} / \mathrm{h}$ \\
\hline 5 & 26.09 .2016 & 56 & $58^{\circ}$ & Riegl VZ-4000 & $18^{\circ} \mathrm{C}, \mathrm{E}, \mathrm{EW} 10 \mathrm{~km} / \mathrm{h}$ \\
\hline 6 & 18.10 .2016 & 59 & $58^{\circ}$ & Riegl VZ-4000 & $11^{\circ} \mathrm{C}, \mathrm{SSW} 18 \mathrm{~km} / \mathrm{h}$ \\
\hline 7 & 22.12 .2016 & 58 & $60^{\circ}$ & Riegl VZ-4000 & $-1^{\circ} \mathrm{C}, \mathrm{SSW} 20 \mathrm{~km} / \mathrm{h}$ \\
\hline 8 & 09.06 .2017 & 57.5 & $57^{\circ}$ & Riegl VZ-4000 & $23^{\circ} \mathrm{C}, \mathrm{SE} 9 \mathrm{~km} / \mathrm{h}$ \\
\hline
\end{tabular}

Another example of laser scanning applications is related to the building of Saint Cross church in BytomMiechowice, Fig. 13. The aim of measurement was to determine curvatures of masonry construction as an indicator of effort construction.

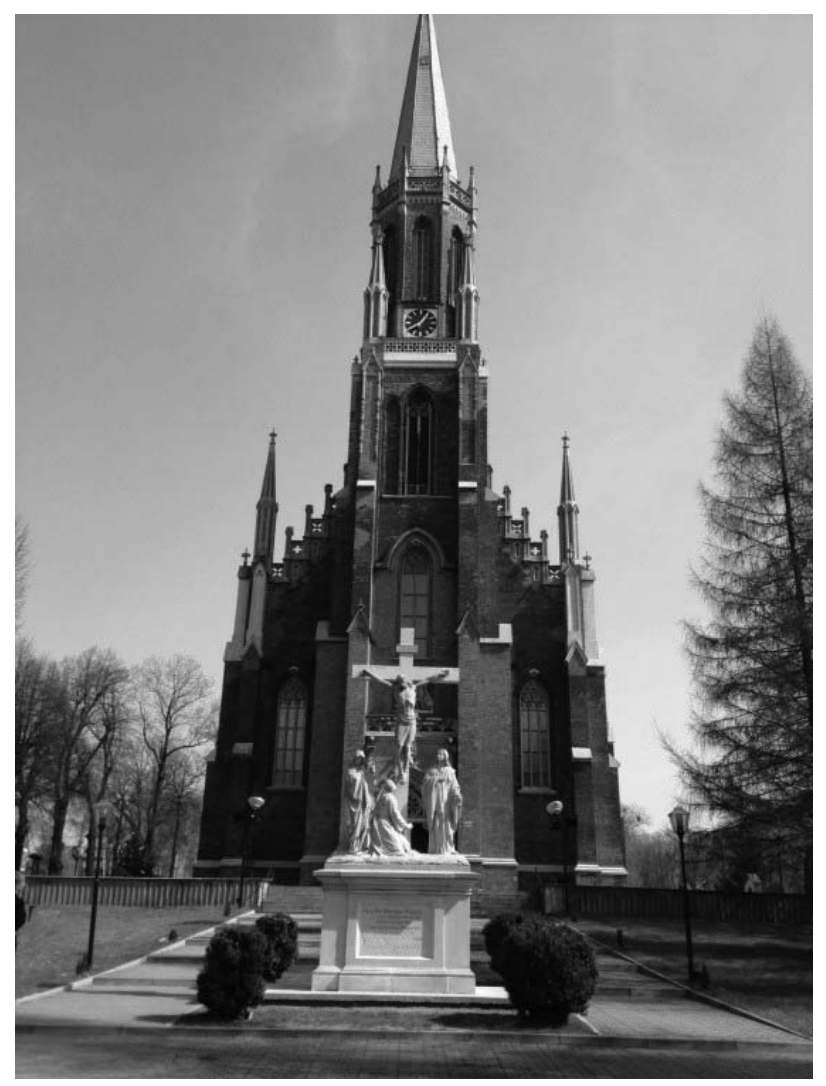

Fig. 13. Building of St. Cross church in Bytom-Miechowice.

Vertical curvatures of the church walls (Fig. 14) were calculated on the basis of points coordinates along particular lines in plane of the walls (Fig. 15).

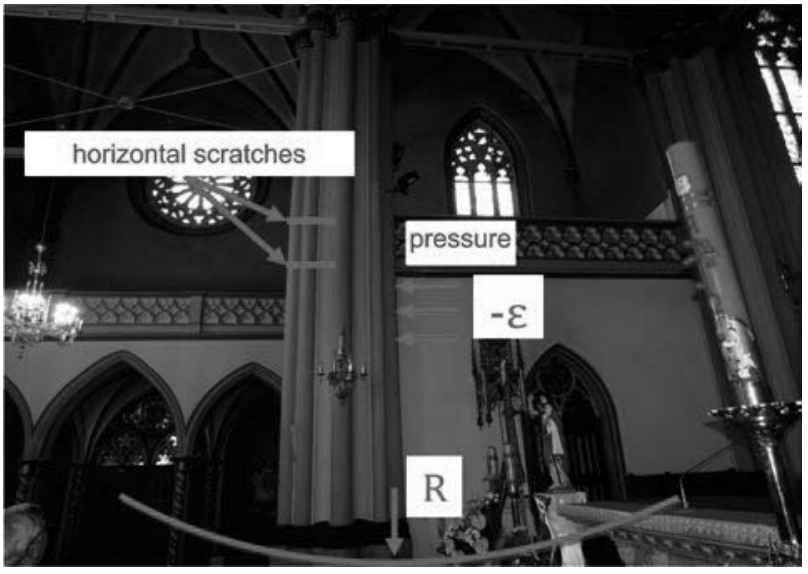

Fig. 14. Scheme of interaction of deformation indicators on construction of church building.

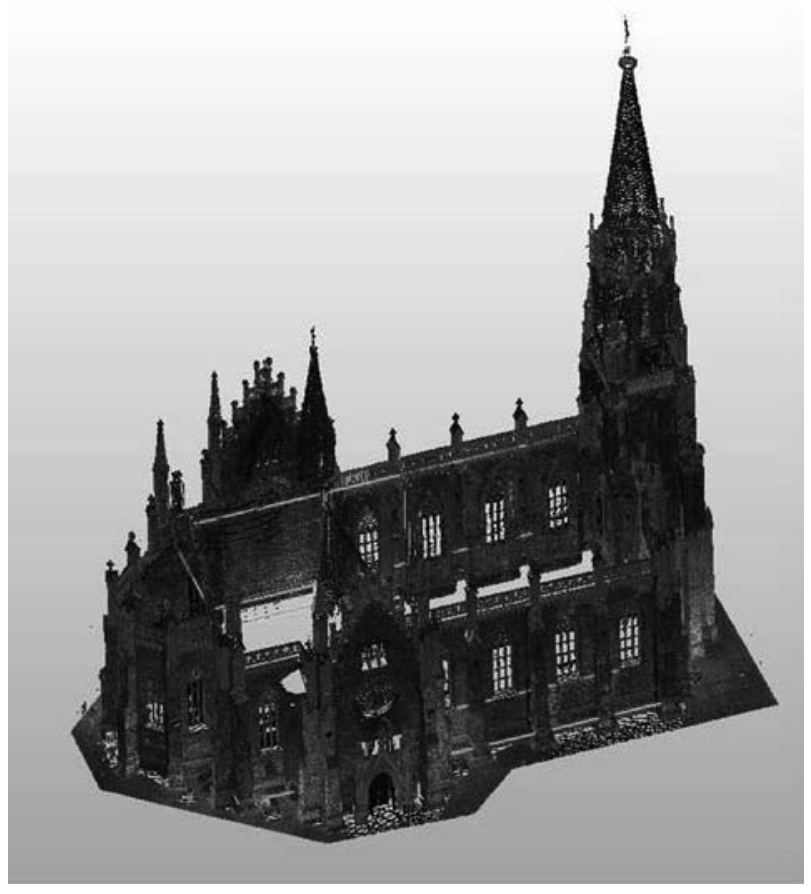

Fig. 15. Horizontal lines in $3 \mathrm{D}$ model of the church building to determine curvatures. 


\subsection{Unmanned Aerial Vehicles}

In last year (2016-2017) drones are more popular to review the condition of inaccessible parts of structure construction. Among others they are used to review the condition of brickwork of high chimney Terma-Dom (section 2.3) and damages of the Saint Wawrzyniec church building in Ruda Sląska-Wirek.

Drone is a popular term of unmanned aerial vehicle. It's controlled by qualified operator from ground using remote system and can be programmed to fly along designed trail.

In Central Mining Institute two types of drone are in service, the larger one Quadrocopter Phantom (Fig. 16) and the smaller one scout DJI Mavic Pro (Fig. 17).

Drones are designed to record photo and video material. They can be used in cartography to make orthophotomosaics and to review the construction of structures, power networks, etc.

The review results of $113 \mathrm{~m}$ high chimney (application of Quadrocopter Phantom drone) and church building (application of DJI Mavic Pro drone) are shown sequentially in photographs 1-7.

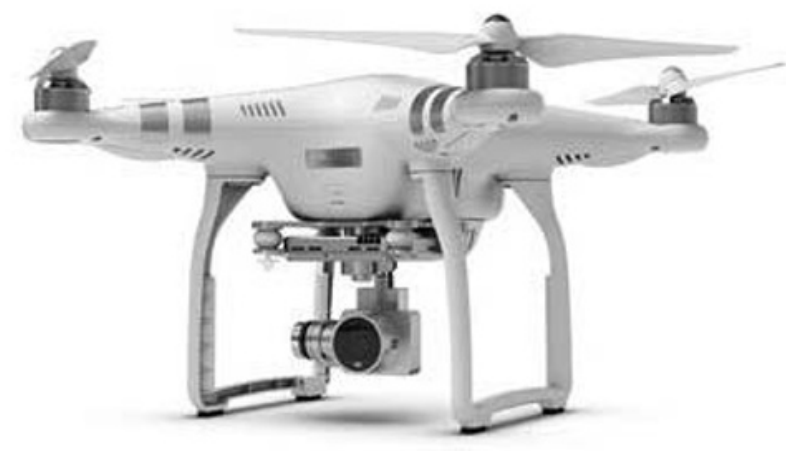

Fig. 16. Drone Quadrocopter Phantom.

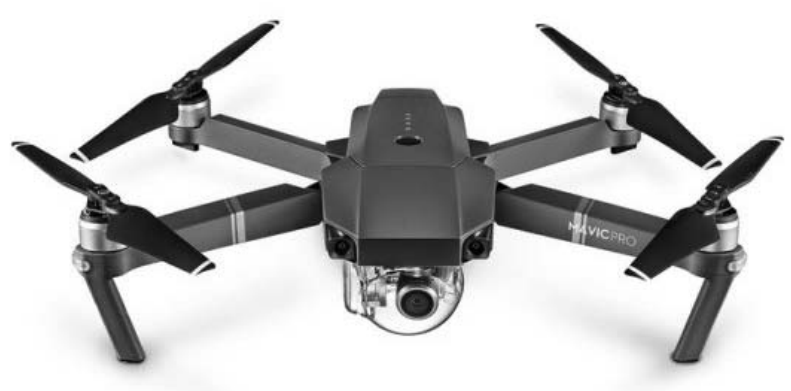

Fig. 17. Drone scout DJI Mavic Pro.

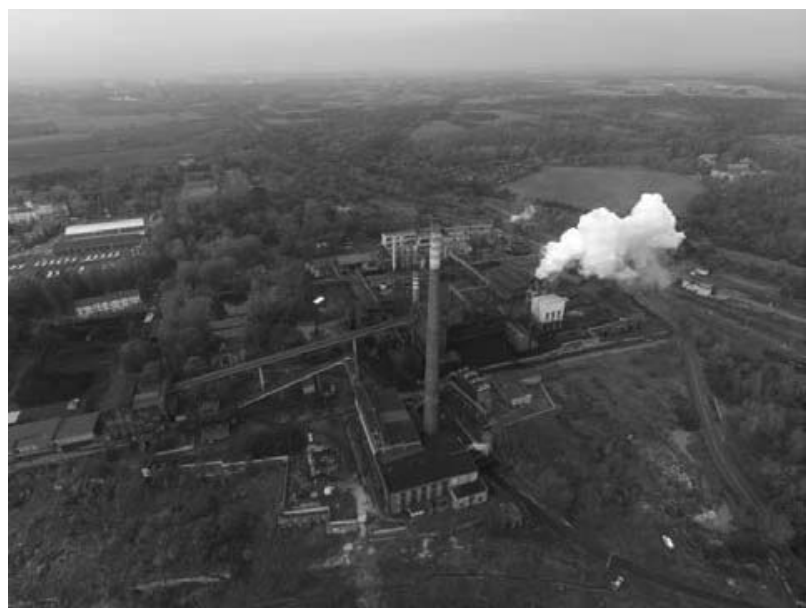

Photo 1. View of Jadwiga coke plant and structures of heat station with Terma-Dom chimney.

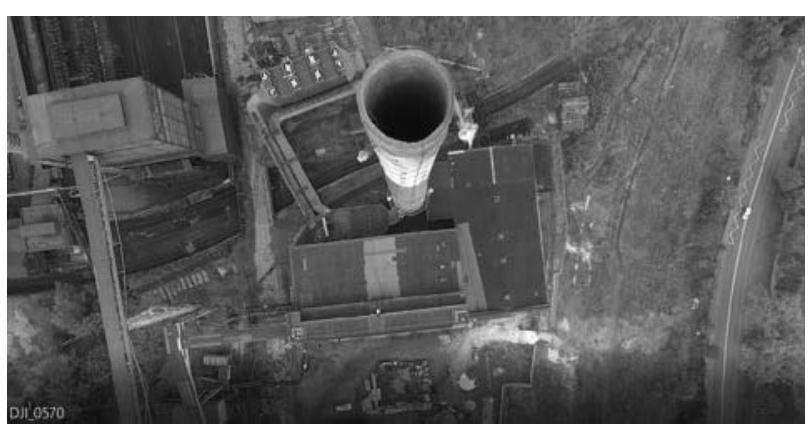

Photo 2. Top of Terma-Dom chimney.

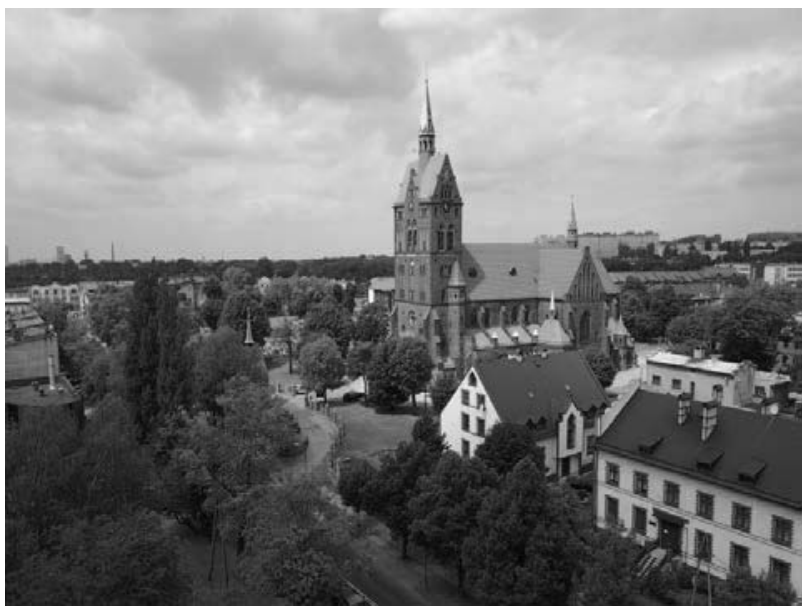

Photo 3. View of St. Wawrzyniec church in Ruda Śląska Wirek. 


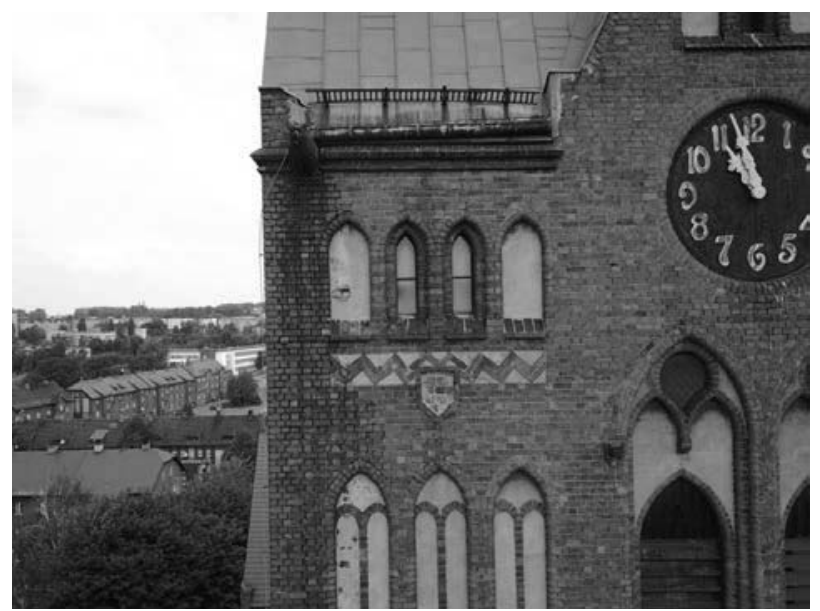

Photo 4. View of the church tower, close-up on the upper part of the tower for inspection of damages in the wall.

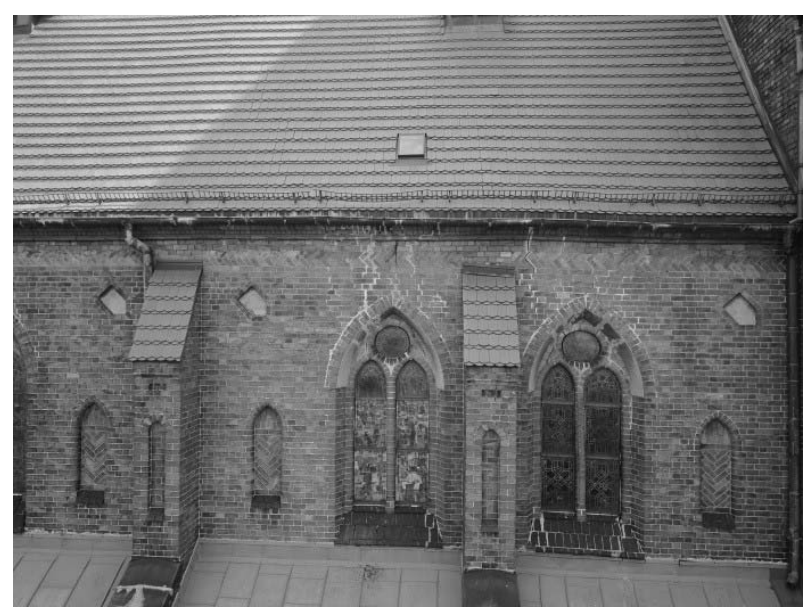

Photo 5. View of the western wall of the church nearby tower (cemetery side), visible fissures and rosette deformation.

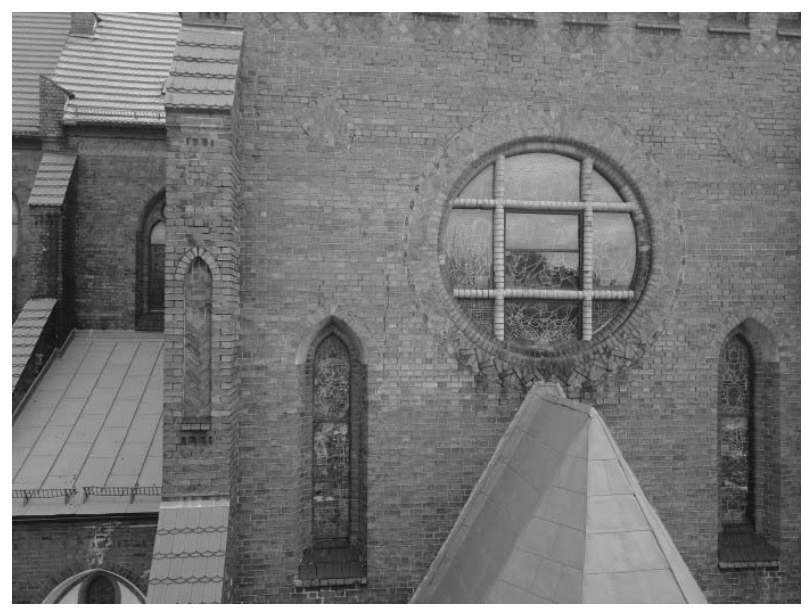

Photo 6. View of the western wall of the church nearby transept (vertical fissures).

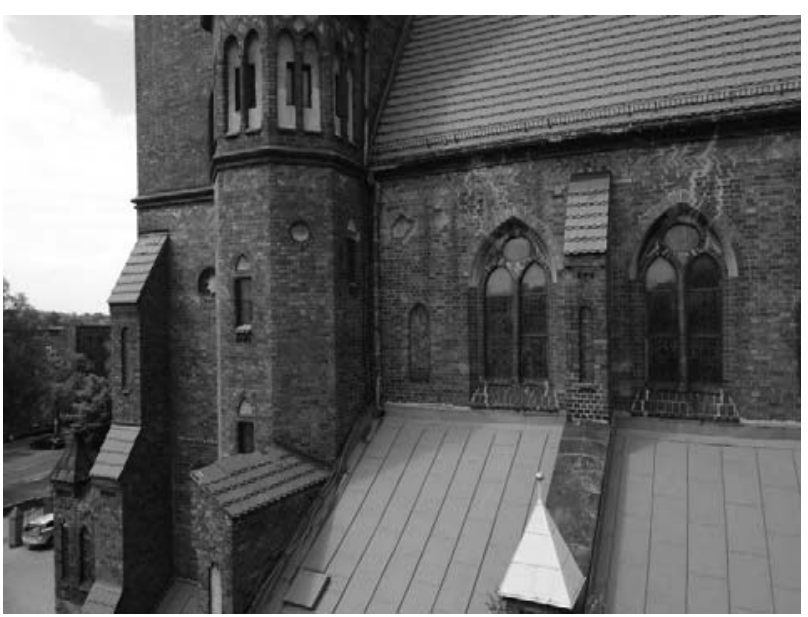

Photo 7. The Eastern wall of the church nearby tower (fissures and rosette deformation).

\section{Conclusions}

Experience from measurement sessions with application of laser and string sensors to observation of structures deformation indicates their expediency as supplement of classic geodetic methods. Their advantages are continuous and real-time observation, remote transmission of data and signalling of exceeding threshold values.

Terrestrial laser scanning is a source of accurate data to monitor condition of structures and review of mining damages. 3D mapping enables further operation including analyze of measurement results and modeling. Laser scanning brings new quality for monitoring and inventory of mining damages.

Application of drones enables to observation of parts of buildings, which are inaccessible for classic geodetic methods.

\section{References}

1. A. Kowalski, Deformacje powierzchni w Górnośląskim Zagłębiu Węglowym (Wydawnictwo Głównego Instytutu Górnictwa, 2015)

2. A. Kanciruk, Arch. Min. Sci., 15 (2012)

3. L. Klabis and A. Kowalski, Przegląd Górniczy, 8, 62-70 (2013)

4. L. Florkowska and A. Kanciruk, [In:] Ochrona obiektów na terenach górniczych (Wydawnictwo Głównego Instytutu Górnictwa, Katowice, 2012)

5. P. Gruchlik, Przegląd Górniczy, 5 (2015)

6. T. Niemiec and P. Gruchlik, Geoinformatica Polonica, 15, 103-112 (2015) 